\title{
Identifying needs and solutions
}

\author{
By JoAn S. Segal \\ Executive Director, $A C R L$
}

\section{The role of librarians in historically black colleges and}

\author{
universities.
}

T wenty-eight librarians from Historically Black Colleges and Universities (HBCU's) met in Atlanta on October 18-20 to discuss plans for an ACRL project to help HBCU libraries. A planning grant from the Andrew W. Mellon Foundation underwrote the cost of the meeting.

Public and private institutions from 12 states and the District of Columbia convened to identify the needs and suggest solutions to the problems of libraries in HBCU's. The meeting began late Sunday afternoon with a wine and cheese reception hosted by the Atlanta University (AU) Library School and Woodruff Library, and sponsored by Blackwell/North America. At dinner the group was welcomed by AU Center provost Prince Rivers, committee chair Beverly Lynch, and ACRL vice president-president elect Joseph A. Boisse.

Keynote speaker Samuel Proctor addressed the group on Monday morning. Proctor, pastor of the Abyssinian Baptist Church in New York City, is a former president of Virginia Union University (1955-1960) and North Carolina A \& T State University (1960-1964). From 1964 to 1984 he was Martin Luther King Professor in the Graduate School of Education at Rutgers. Since his retirement in 1984 he has been professor emeritus there.

Proctor stressed the needs of HBCU students in his address to the librarians. These needs, he said, are met not only in the classroom, but by the entire academic community, including the library. Today's black students are culturally isolated. They come with academic deficiencies, but also-more seriously - with acute attitudinal problems that hinder their ability to learn or to accept even legitimate authority. Their life experiences have left them trapped in an intellectual conundrum, not knowing what their commitment should be. While all young people face an identity problem, the "Who am $\mathbf{I}$ " question is more serious for the black student. The multiplicity of cultural objectives means they must live in and adapt to a culture that is not theirs, while keeping in touch with and maintaining appreciation for black history and culture. He described this as an "amphibious existence," where one must be able to adapt to and cope successfully in one or the other environment upon demand. Referring to DuBois' "two personalities" concept, he stressed the need for black students to learn to live in both cultures and hence the importance of inducting them into the life of the mind.

Proctor cited his experience in a tradition where he was taught that blacks must do equally well as whites at what whites do; as he put it, "play the same clarinet, but play it better." The post-1960s culture instructs that blacks need not subscribe unquestioningly to the culture of the majority. But these advances have not yet led to a reconciled understanding or an intellectual justification of the need for cultural duality, and a serious barrier to learning exists. Proctor teaches his students to learn their black heritage, but to realize that their fortunes lie in this country and that they must know the dominant culture too,

An aw areness of the plight of these students leads logically to increased library involvement in their education. Faculty who don't use library resources 


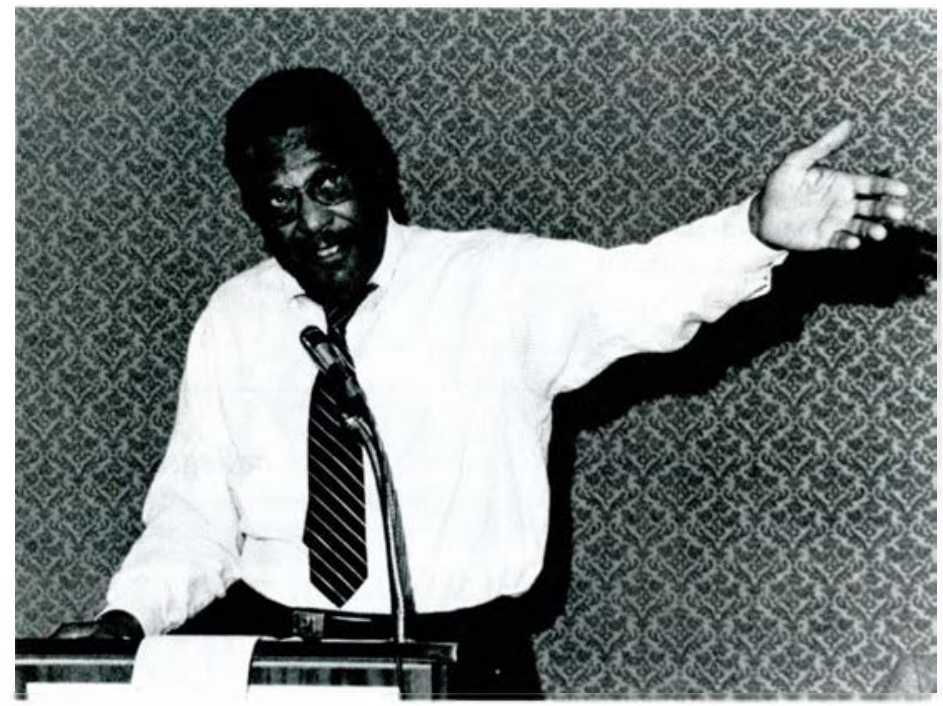

Samuel Proctor, professor emeritus in the Rutgers Graduate School of Education.

with students are "playing our children cheap," he accused. Too many "textbook campuses" exist where "Pablumized" textbook information, instead of being used as an introduction to a subject, constitutes all the exposure to a subject that a student gets. The drive to expose students to a broader literature and knowledge can create a truly intellectual atmosphere ("tone") on a campus, with the library as one key to change. Librarians, he asserted, are not warehouse keepers or exterminators (of book-destroying forces) - they are "head" people, too smart to be errand persons. Libraries are places where ideas are buried for faculty and students to dig out.

Librarians should play a significant mentoring role for inquisitive students, claiming them for the life of the mind and encouraging them to study independently under the guidance of librarians and others. "We dorit know," he said, "who these people are. They may be leaders of the future-a Jesse Jackson or a Douglas Wilder."

Encouraging librarians to take an activist stance in their relations with academic administrators, he suggested we rethink librarians' roles and functions in contributing to the effectiveness of higher education.

Proctor's inspirational message was followed by a historical review of programs targeted toward black librarianship. Accounts of several key projects, including the ACRL/Mellon internship pro- grams (1974-1978), the National Agricultural Library's work with the $1890 \mathrm{~s}$ Land Grant Colleges and Tuskegee Institute (which included an internship component), the Southern Education Foundation/Mellon project that will give over $\$ 2$ million for humanities collection development in private HBCU's, and a recent FIPSE project on computerbased services (directed by Lorene Brown) which trained librarians, established contracts, collected statistics, and provided workshops.

Small groups then worked on identifying problems and needs and suggesting solutions. The Tuesday morning session synthesized the group work into the following major themes:

Image building: the need to impress on academic administrators the importance of libraries in institutional effectiveness.

Accreditation; with all HBCU's facing reaccreditation within 5 - 10 years, there is a need to help the librarians prepare to participate actively and to influence accrediting bodies.

Staffing: demands for more and better-qualified staff; recruitment problems; the need for staff development especially in teaching, management, and automation. Questions of library education; suggestions for staff and faculty reciprocal exchanges; need for assistance to pay for tuition, travel for staff development.

Facilities: problems of buildings inadequate to support new technologies; preservation, conserva-

\section{$718 / C \dot{R} L$ News}


tion, and restoration of materials; the need for help in planning.

Networking and automation: the great need for consulting help; planning; ongoing cost problems; difficulties with funding present cooperatives; the desire for shared access to national bibliographic databases and collections.

Collection Development: questions about faculty cooperation, funding (including money for processing), and special collections.

Bibliographic Instruction: jdeas on tying in with collection development; the pros and cons of faculty involvement; program planning; disciplinary training for course-related BI programs.

The meeting adjourned at 11:15 a.m., after hearing committee chair Beverly Lynch's promise to move forward with all due haste to set up one or more projects and seek the necessary funding.

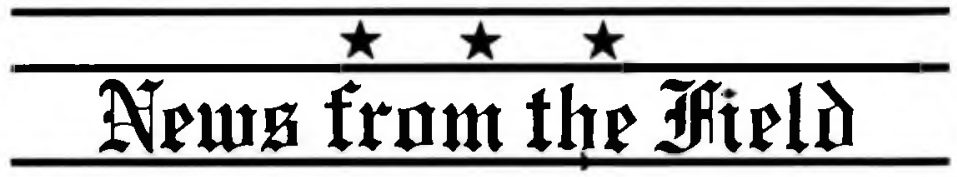

\section{Acquisitions}

- George Washington University, Washington, D.C., has acquired a number of manuscript and archival collections to support research on the past and contemporary history of the city of Washington. One collection is the papers of Polly Shackleton, who served on the D.C. Council for 16 years; the collection includes information on planning, zoning, and human services. The Library has also acquired the records of the Committee of 100 on the Federal City, a private citizens' organization overseeing major city planning issues. Organized in 1923, the Committee has been active in areas such as conservation, historic preservation, and land use planning. Other acquisitions of note include the archives of the Greater Washington Board of Trade, consisting of 200 linear feet of records dating from 1889 to 1980 ; the archives of the Jewish Community Council of Greater Washington; and a group of papers on the history of the Metrorail system, including plans, memoranda, reports, and oral histories.

- Idaho State University, Pocatello, has received the entire library of Glenn E. Tyler, late chairman of the History Department and an ISU faculty member from 1955 to 1975 . The approximately 22,000 books and manuscripts cover a variety of topics, with noteworthy collections on the history of science and the Reformation period, especially Calvinism and Puritanism. More than a hundred rare volumes include the collected sermons of John Calvin on the Book of Job, printed in 1584, Other notable items are a second edition of Sprat's History of the Royal Society (1702), Isaac Newton's Observations upon the Prophesies of Daniel and the Apocalypse of John (1733), Doumergue's seven-volume biography of Calvin, and a group of works on English and American Puritanism. In accordance with Tyler's wish, all of the books except those requiring special care and attention will become part of the regular circulating collection. They will be identified by a specially designed bookplate.

- Johns Hopkins University, Baltimore, Maryland, has been chosen as the repository for the archives of the Association of American Universities. The records consist of correspondence, committee minutes and reports, annual conference materials, and office files. Founded in 1900 , the AAU now includes 54 American and 2 Canadian universities. Johns Hopkins University was a founding member.

-The Library of Congress, Washington, D.C., has acquired 44 volumes that once belonged to Thomas Jefferson (1743-1826), the gift of Mary Gresham Machen, Mr. and Mrs. Arthur Machen Jr. and Mr. and Mrs. C. Harvey Palmer Jr. The books are part of the collection Jefferson formed after he sold his library to Congress in 1815 to replace books burned by British soldiers during the War of 1812. That library became the foundation of the Library of Congress. In his later years, Jefferson's literary interests focused on the classics, in their original languages as well as in English. In the collection is an eight-volume set of the Works of Tacitus, Jefferson's favorite Roman author, and a 12volume collection of Cicero's Letters. Both contain marginal corrections of grammatical errors in Jefferson's hand. Jefferson's copy of Plato's Republic - a work he disliked - and works by Aristophanes, Horace and Homer are also included. The collection was first purchased in 1829 by Lewis Henry Machen, later principal clerk of the Senate, at an auction following Jefferson's death, and passed through successive generations of his family.

- Portland State University, Oregon, has received the Italian history research library developed by George A. Carbone, professor emeritus of history. Consisting of mоге than 1,300 volumes, the collection includes books and pamphlets on 19th- and 20th-century Italy and the diplomatic 